\title{
Oh where, oh where can that little nodule be?
}

\author{
Stephen C. Yang, MD
}

See related article on pages 26-32.

The intraoperative localization of small pulmonary nodules remains the paramount concern of the surgeon, in part to avoid an open thoracotomy (reports of around $50 \%$ conversion rates) but more importantly to leave the operation with a definitive diagnosis. This has become an increasing problem because of the enhanced identification of small lung nodules with lung cancer computed tomographic screening. During the last 2 decades, with the increasing use of video-assisted thoracoscopic surgery, a number of localization techniques have been reported, each technique with its own advantages and drawbacks.

These approaches can be divided into 3 broad categories. The first group consists of the injection of targeting agents, such as contrast agents, dyes, or radioisotopes. These can be placed either percutaneously or endobronchially. The primary limitation is the diffusion of the agent away from the primary site, restricting the time between injection and surgical resection. This poses difficulty inn the timing of the surgery and does not allow for variability in the operating room schedule. In addition, there may be potential risks of anaphylaxis and embolization.

The second group involves intraoperative imaging with computed tomography or ultrasonography. Real-time computed tomographically guided video-assisted thoracoscopic surgical resections are cumbersome because of the added equipment and cost; in addition, artifacts can be generated with the surrounding instruments and staplers. Ultrasonography requires complete collapse of the lung, and results are difficult to interpret in emphysematous tissue or for deep lesions.

The final group includes the preoperative insertion of wires and microcoils. Localization wires pose the same problems as targeting agents, because proper timing before

\footnotetext{
From the Division of Thoracic Surgery, Department of Surgery, The Johns Hopkins Medical Institutions, Baltimore, Md.

Disclosures: Author has nothing to disclose with regard to commercial support.

Received for publication Sept 22, 2014; accepted for publication Sept 22, 2014; available ahead of print Oct 24, 2014.

Address for reprints: Stephen C. Yang, MD, The Arthur B. and Patricia B. Modell Endowed Chair in Thoracic Surgery, The Johns Hopkins Medical Institutions, 600 N Wolfe St, Blalock 240, Baltimore, MD 21287 (E-mail: syang@jhmi.edu). J Thorac Cardiovasc Surg 2015;149:33-4 $0022-5223 / \$ 36.00$

Copyright (C) 2015 by The American Association for Thoracic Surgery http://dx.doi.org/10.1016/j.jtcvs.2014.09.080
}

surgical resection is critical. In addition, the large gauge of these wires can lead to pneumothoraces, obviously causing concern before positive-pressure ventilation. Microcoils have the benefit of causing little tissue trauma, because they are soft and pliable. Reportedly, early microcoils have uncoiled; however, because of the local adhesion characteristics, they do not dislodge or embolize. Finally, placement does not need to be on the day of surgery, unlike the dyes and contrast, taking pressure of with respect to precise timing of resection.

Finley and colleagues ${ }^{1}$ present in this month's issue of the Journal of Thoracic and Cardiovascular Surgery their experience with the preoperative percutaneous insertion of a microcoil and the use of intraoperative fluoroscopy to aid in resection of the appropriate lung tissue. This is one of the first randomized trials to use a localization technique that is clinically relevant and has practical applicability. They showed a lower conversion rate to thoracotomy and decreased need for anatomic resection without a subsequent increase in overall cost. The technique itself was first described in $1994^{2}$; curiously and for unknown reasons, it has not emerged until recent years to become a popular alternative.

One should be cautious if this technique is generally adopted, and not use it for all routine resections. It is not clear whether this approach should be used for lesions that traditionally the surgeon would expect to be "easy" to approach (for example, a nodule at the edge of the lower lobe, lingual, or apex of the upper lobe) or where, on the basis of imaging, one has a reasonable expectation that a "blind" wedge will get at the nodule. In addition, contraindications for this procedure (such as lesion depth, presence of pulmonary hypertension or bullous emphysema) are not clear. It should prove useful for the resection of small and deep pulmonary nodules or ground-glass opacities. This technique should allow a fine-needle aspiration biopsy at the time of coil deployment, which may ultimately change the strategy for those patients who need more or less of an anatomic dissection. Likewise, the utility of the coil to provide margins of resection is an added benefit of this technique.

These encouraging results, however, should not supplant the review of computed tomographic scans with 3-dimensional reconstructions and the mastery of segmental anatomy and video-assisted thoracoscopic surgical segmentectomies by thoracic surgeons. In this age when smaller nodules are being found on screening examinations, it becomes paramount to remember that patients deserve a safe and effective approach in 
ascertaining a diagnosis, because they often rely on us for the final and definitive procedure.

\section{References}

1. Finley FJ, Mayo JR, Grant K, Clifton JC, English J, Leo J, et al Preoperative computed tomography-guided microcoil localization of small peripheral pulmonary nodules: a prospective randomized controlled trial. J Thorac Cardiovasc Surg. 2015;149:26-32.

2. Asamura H, Kondo H, Naruke T, Tsuchiya R, Wakao F, Kaneko M, Suemasu K. Computed tomography-guided coil injection and thoracoscopic pulmonary resection under roentgenographic fluoroscopy. Ann Thorac Surg. $1994 ; 58: 1542-4$

Access to The Journal of Thoracic and Cardiovascular Surgery Online is reserved for print subscribers!

Full-text access to The Journal of Thoracic and Cardiovascular Surgery Online is available for all print subscribers. To activate your individual online subscription, please visit The Journal of Thoracic and Cardiovascular Surgery Online, point your browser to http://www.mosby.com/jtcvs, follow the prompts to activate your online access, and follow the instructions. To activate your account, you will need your subscriber account number, which you can find on your mailing label (note: the number of digits in your subscriber account number varies from 6 to 10 ). See the example below in which the subscriber account number has been circled:

\section{Sample mailing label}

This is your subscription account number

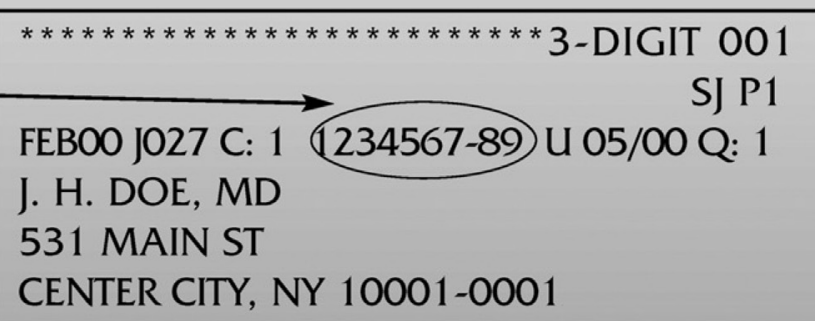

Personal subscriptions to The Journal of Thoracic and Cardiovascular Surgery Online are for individual use only and may not be transferred. Use of The Journal of Thoracic and Cardiovascular Surgery Online is subject to agreement to the terms and conditions as indicated online. 